\title{
Pencirian Mikroskopi Butiran Kuarza Laut Cetek Muara Sungai Kelantan Hingga Pelantar Benua Laut China Selatan, Semenanjung Malaysia
}

(Microscopic Characterization of Quartz Grains of Shallow Water Sungai Kelantan Delta into South China Sea Continental Shelf, Peninsular Malaysia)

\section{Nurul Afifah Mohd RADZIR*, ChE AzIz Ali \& KAMAl Roslan MOHAMED}

\section{ABSTRAK}

Pencirian butiran kuarza berskala mikro dengan menggunakan mikroskop pengimbas elektron (SEM) menemukan beberapa jenis kuarza yang mempunyai tekstur dan morfologi butiran kuarza berbeza. Penggunaan kaedah ini telah berjaya mengenal pasti enam jenis butiran kuarza iaitu kuarza jenis $A, B, C, D, E$ dan F. Pengelasan dibuat berdasarkan tekstur dan morfologi butiran yang menggambarkan sejarah pengangkutan (proses mekanik) dan pengendapan yang telah dilalui oleh butiran kuarza tersebut. Keenam-enam jenis kuarza tersebut diterbitkan oleh dua faktor geologi iaitu genetik butiran kuarza dan proses mekanik semasa pengangkutan. Hasil daripada pembahagian faktor ini, dua wilayah taburan jenis butiran kuarza telah dikenal pasti iaitu wilayah I dan wilayah II. Wilayah I mencirikan kuarza yang mengalami proses mekanik lemah sehingga sederhana dan dikenal pasti sebagai sedimen Resen yang diangkut melalui Sungai Kelantan sebelum dienapkan ke dalam kawasan lembangan Laut China Selatan. Sedimen Resen ini menunjukkan tekstur permukaan yang tidak kasar dicirikan oleh tanda V berdiameter $<2 \mu \mathrm{m}$ atau tiada dan berbentuk bulat hingga bersegi. Manakala, wilayah II pula mempunyai butiran kuarza yang telah mengalami proses mekanik yang sederhana tinggi sehingga sangat tinggi. Sedimen yang dicerap di wilayah II ini merupakan campuran sedimen Resen dan sedimen baki yang terdiri daripada sedimen sub-arkos lautan yang telah dienapkan sejak 5000 tahun lampau. Sedimen sub-arkos lautan ini mengalami beberapa kali proses mekanik yang menghasilkan tekstur yang kasar, tanda $V<2 \mu m$ hingga $>2$ $\mu \mathrm{m}$ dan lelasan yang tinggi pada permukaan kuarza dan morfologi yang bulat hingga hampir sfera.

Kata kunci: Morfologi kuarza; proses mekanik; sedimen baki; sedimen resen; tekstur kuarza

\section{ABSTRACT}

Characterization of quartz grains by using scanning electron microscopy (SEM) has identified several quartz types with different textures and morphologies. By using this method, six types of quartz grains have been identified which are quartz type $A, B, C, D, E$ and $F$ based on textures and morphologies recorded during transportation (mechanical processes). The six types of quartz are the results of two factors which are genetic of quartz and mechanical processes during transportation. As a result of the distribution of this factors, two suites of detrital quartz was discovered which are province I and province II. Province I is characterised by distribution of low energy with poor mechanical processes and consists of recent sediments which was transported by the Sungai Kelantan. The recent sediments showed smooth to moderate rough surface texture with $V$ marks size $<2 \mu \mathrm{m}$ or absent and have rounded to angular grain shape. Meanwhile, province II is characterised by moderate to high mechanical processes and sediments are represented by a mixture of recent and relict sediments which is known as marine sub-arkosic components that has been deposited since 5000 cal. yr. BP. The marine sub-arkosic components undergone some excessive mechanical processes that produces rough surfaces textures, $V$ marks structure with size $<2 \mu \mathrm{m}$ to $>2 \mu \mathrm{m}$, high abrasion on the surface of quartz and rounded to nearly spherical morphology.

Keywords: Mechanical process; recent sediments; relict sediments; quartz morphology; quartz texture

\section{PENDAHULUAN}

Mineral kuarza adalah salah satu mineral yang boleh digunakan untuk menentu ukur sejarah proses geologi, pengangkutan dan pengendapan yang telah dilalui oleh sesuatu sedimen. Mineral kuarza ini merakam sejarah geologi pada permukaannya secara mikro dalam bentuk tekstur permukaan, manakala rekod sejarah pengangkutan pula dirakam melalui bentuk morfologi samada bulat sehingga subsegi. Kajian terhadap tekstur permukaan kuarza telah bermula lebih sedekad lalu dan kajian ini menumpukan terhadap tekstur permukaan mineral bagi mengenal pasti sekitaran endapan dan proses pengangkutan yang dialami oleh butiran kuarza tersebut.

Mineral kuarza ini boleh dijadikan sebagai penunjuk kepada penentuan asalan dan proses pengangkutan yang dilalui di dalam air sebelum dienapkan di kawasan 
lembangan. Menurut Basu (1976), Basu et al. (1975) dan Kasper-Zubillaga (2009), kehadiran mineral kuarza yang selalunya dominan dalam ketiga-tiga jenis batuan yang wujud di dunia menjadikan mineral ini amat penting dalam penentuan kebulatan dan juga asalannya. Sifat kerintangan yang tinggi terhadap luluhawa menjadikan mineral ini mineral penting dalam menganalisis sejarah yang dialami oleh butiran kuarza tersebut. Antara pengkaji yang telah menggunakan mineral ini bagi mengenal pasti sejarah geologi yang telah berlaku adalah seperti Kravitz (1976); Krinsley dan Doornkamp (1973); Morgalis dan Krinsley (1971); Suresh et al. (2010); Whalley dan Krinsley (1974) serta Young (1976). Penilaian lengkap terhadap kuarza juga boleh digunakan untuk mengenal pasti proses yang telah memberi impak kepada tekstur dan morfologi mineral tersebut, seterusnya memberi penjelasan mengenai perubahan tenaga dan keadaan persekitaran yang dialami oleh mineral kuarza tersebut (Whalley \& Krinsley 1974).

Penyelidikan ini dijalankan untuk menganalisis morfologi dan tekstur butiran kuarza yang wujud di dalam lembangan Laut China Selatan dan seterusnya mengenal pasti asalan dan proses yang dialami oleh butiran kuarza. Penunjuk asalan dan proses yang direkod oleh mineral kuarza ini akan dibahagikan kepada wilayah dan ia akan menjelaskan sumber sebenar butiran kuarza yang tertabur secara rawak di kawasan kajian. Istilah dan tafsiran yang digunakan di dalam kertas ini adalah berdasarkan kajian awal oleh Krinsley dan Doornkamp (1973), Margolis dan Krinsley $(1974,1971)$ serta Whalley dan Krinsley (1974).

\section{KAEDAH KAJIAN}

Kaedah persampelan secara bersistem telah dijalankan pada sela yang tetap iaitu $\sim 3 \mathrm{~km}$. Sampel telah diambil daripada 65 lokaliti dalam kawasan seluas $\sim 1386 \mathrm{~km}^{2}$ bermula daripada kawasan luar muara Kuala Besar sehingga $33 \mathrm{~km}$ ke arah Laut China Selatan (Rajah 1). Sampel permukaan diambil dengan menggunakan pencekup sampel dan disimpan di dalam bekas sampel.

Penyediaan sampel untuk analisis mikroskopi dijalankan dengan mengasingkan bahan organik di dalam sampel pasir yang telah dikeringkan. Sebanyak tiga butir sampel pasir dilekatkan di atas pita pelekat dan diletakkan di atas pelantar peralatan elektron mikroskop jenis Hitachi TM1000 TableTop. Kedudukan pelantar dilaraskan bagi mendapatkan imej pasir yang diperlukan melalui komputer berperisian Hitachi TM1000. Skala pembesaran mikroskop, kecerahan dan kontras imej turut dipadankan bagi mendapatkan imej pasir yang jelas dan bagus. Skala pembesaran yang digunakan semasa imej diambil adalah seperti Jadual 1.

\section{HASIL}

Kajian menggunakan kaedah mikroskopi ini telah mengenal pasti enam jenis butiran kuarza dengan ciri tekstur permukaan yang berbeza.

\section{KUARZA JENIS A}

Kuarza jenis A ialah kuarza daripada lokaliti 23 (Rajah 2) yang mempunyai garis sudut yang tajam dan kasar dengan hujung butiran yang tidak sekata. Tekstur permukaan menunjukkan pecahan dan terdapat satah retakan pada permukaan butiran kuarza. Permukaannya juga tidak menunjukkan kehadiran tanda V. Butiran ini berkemungkinan mengalami proses mekanik yang berterusan bermula daripada pemecahan daripada batuan induk sehingga proses lelasan dengan butiran sedimen yang lain semasa diangkut di dalam air sungai.

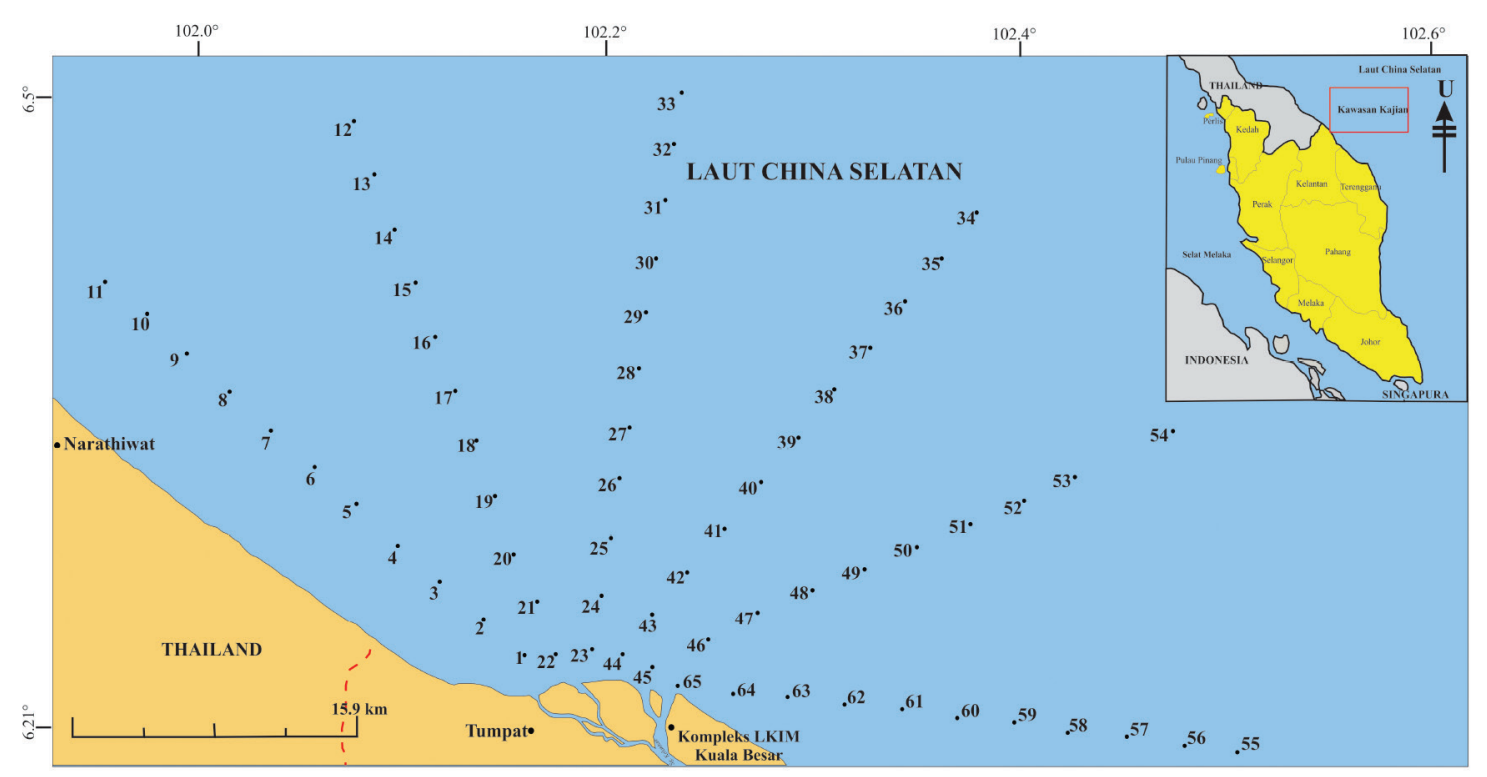

RAJAH 1. Peta kawasan kajian dan lokaliti persampelan 
JADUAL 1. Skala pembesaran yang digunakan dalam kaedah elektron mikroskopi butiran pasir

\begin{tabular}{|c|c|c|c|}
\hline Lokaliti sampel & Saiz sampel & $\begin{array}{c}\text { Skala pembesaran imej } \\
\text { lengkap }\end{array}$ & $\begin{array}{l}\text { Skala pembesaran } \\
\text { permukaan sampel }\end{array}$ \\
\hline 23 & Pasir halus & $\times 800$ & - \\
\hline 24 & Pasir halus & $\times 800$ & - \\
\hline 25 & Pasir halus & $\times 1200$ & - \\
\hline \multirow{2}{*}{26} & Pasir halus & $\times 200$ & $\times 800$ \\
\hline & Pasir sederhana & $\times 80$ & $\times 500$ \\
\hline \multirow{3}{*}{29} & Pasir halus & $\times 200$ & $\times 500$ \\
\hline & Pasir sederhana & $\times 80$ & $\times 800$ \\
\hline & Pasir Kasar & $\times 40$ & $\times 500$ \\
\hline \multirow{3}{*}{31} & Pasir halus & $\times 200$ & $\times 500$ \\
\hline & Pasir sederhana & $\times 80$ & $\times 800$ \\
\hline & Pasir Kasar & $\times 40$ & $\times 500$ \\
\hline \multirow{3}{*}{33} & Pasir halus & $\times 200$ & $\times 500$ \\
\hline & Pasir sederhana & $\times 80$ & $\times 800$ \\
\hline & Pasir Kasar & $\times 40$ & $\times 500$ \\
\hline
\end{tabular}

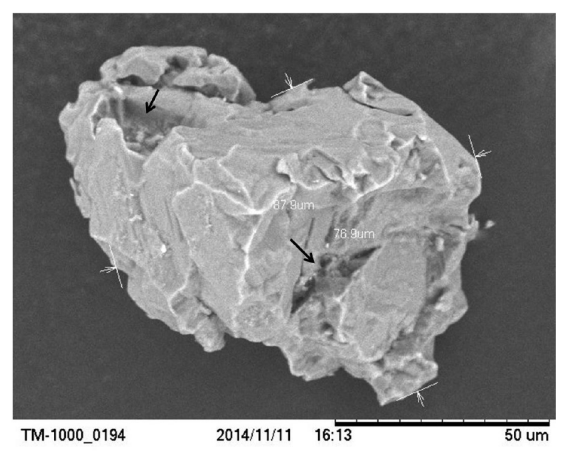

RAJAH 2. Butiran kuarza jenis A (lokaliti 23) bersaiz pasir halus. Anak panah menunjukkan pecahan permukaan kuarza

\section{KUARZA JENIS B}

Kuarza jenis B adalah daripada lokaliti 24 (Rajah 3), mempunyai bentuk seperti serpihan kepingan sedimen panjang yang patah dengan permukaan yang tidak seragam dengan hujung yang tajam. Tekstur permukaannya menunjukkan banyak tanda $\mathrm{V}$ berdiameter $<2 \mu \mathrm{m}$ dan lubang punaran. Keadaan tekstur permukaan dan morfologi butiran jenis ini memberi petunjuk bahawa sedimen telah melalui penguraian pada kadar tenaga yang rendah sehingga sederhana dan mengalami proses mekanik yang hampir sama dengan kuarza jenis A.

\section{KUARZA JENIS C}

Kuarza jenis C (kuarza lokaliti 25) (Rajah 4) menunjukkan butiran kuarza berbentuk bulat dengan permukaan yang menggerutu dan kasap dengan hujung dan bucu yang menonjol. Tekstur permukaannya mempunyai tanda $\mathrm{V}$ pada permukaannya dan terdapat juga lubang

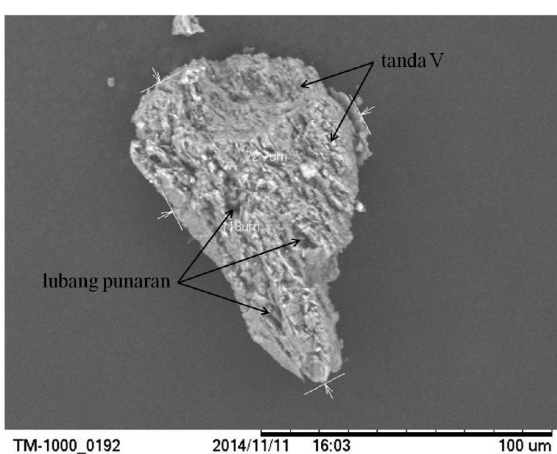

RAJAH 3. Butiran kuarza jenis B (lokaliti 24) bersaiz pasir halus

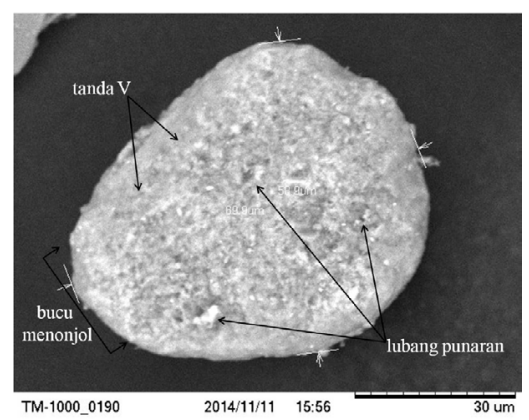

RAJAH 4. Butiran kuarza jenis C (lokaliti 25) bersaiz pasir halus

punaran. Ini menunjukkan bahawa butiran kuarza ini telah mengalami penguraian pada kadar tenaga yang rendah sehingga sederhana seperti kuarza jenis A dan B. Kuarza ini berkemungkinan mengalami pemecahan dan lelasan yang aktif hasil daripada tenaga arus yang 
dibawa oleh air sungai sebelum dilepaskan ke dalam kawasan lembangan.

\section{KUARZA JENIS D}

Kuarza jenis D diambil daripada lokaliti 26 (Rajah 5 dan 6), menunjukkan corak kerosakan dengan bentuk tidak tetap, bersudut tetapi hampir bulat pada pinggir tepi dan juga bentuk cengkung pada permukaan sampel. Tekstur permukaan adalah kasap dan terdapat pecahan yang tidak seragam pada permukaan satah butiran tersebut dengan lubang kecil yang tidak seragam. Selain itu, terdapat puing-puing yang melekat seperti silika menutupi lubang halus pada permukaannya. Pembentukan alur yang tidak sekata juga terdapat pada permukaannya tanda $\mathrm{V}$ yang bersaiz halus (purata saiz tanda $\mathrm{V}$ berkemungkinan $<2$ $\mu \mathrm{m})$. Kuarza jenis ini telah melalui tindakan mekanik yang lebih agresif dan lama berbanding kuarza jenis A, B dan C.
Morfologi kuarza jenis ini menunjukkan kuarza ini telah mengalami pengangkutan atau pergerakan di dasar laut dalam keadaan tenaga yang rendah sehingga sederhana dan berkemungkinan mengalami proses tersebut dalam waktu yang sangat lama.

\section{KUARZA JENIS E}

Butiran kuarza jenis E diwakili oleh kuarza daripada lokaliti 29 dan 31 (Rajah 7 hingga Rajah 12) menunjukkan bucu yang lebih bulat dan menonjol dengan bentuk yang tidak tetap tetapi hampir menyerupai bentuk bulat dengan terdapatnya lubang punaran dan tanda-tanda kesan $\mathrm{V}$ yang bersaiz sekitar $<2 \mu$ m pada permukaannya. Permukaan kuarza menunjukkan pecahan yang tidak seragam dan kesan garisan lelasan dengan pelekatan puing-puing kecil pada permukaan kuarza yang menyebabkan lubang punaran ditutupi dengan zarah kecil tersebut yang

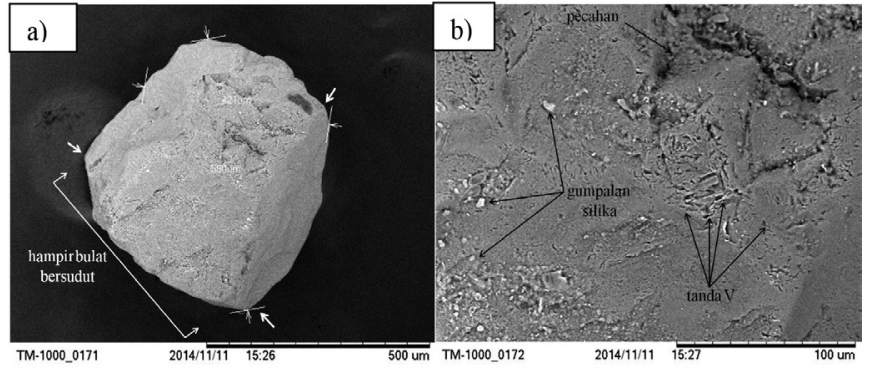

RAJAH 5. Butiran kuarza jenis D (lokaliti 26) bersaiz pasir halus a) Imej bentuk kuarza. Anak panah menunjukkan bucu yang bersudut. b) Imej pembesaran tekstur kuarza

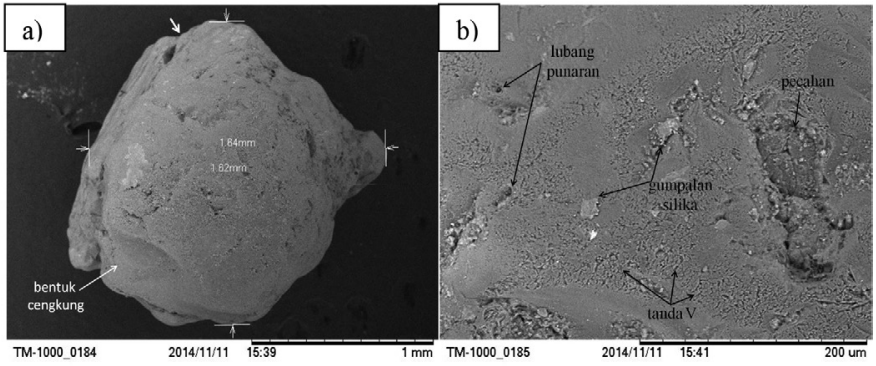

RAJAH 6. Butiran kuarza jenis D (lokaliti 26) bersaiz pasir sederhana a) Imej bentuk kuarza. Anak panah menunjukkan bucu yang bersudut. b) Imej pembesaran tekstur kuarza

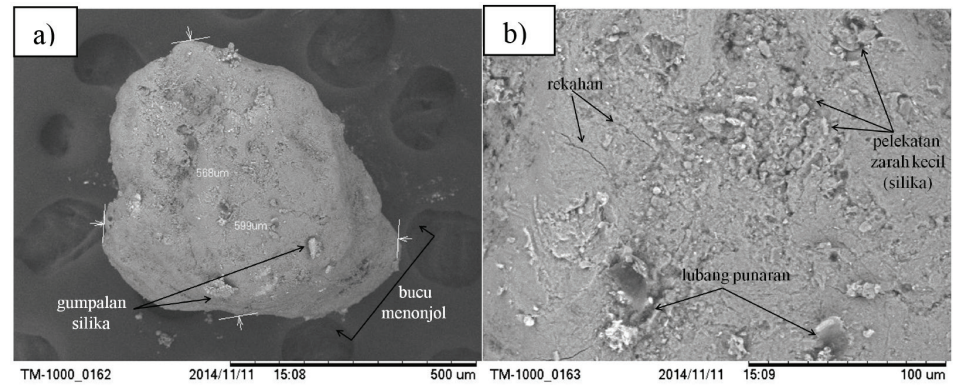

RAJAH 7. Butiran kuarza jenis E (lokaliti 29) bersaiz pasir halus a) Imej bentuk kuarza dan b) Imej pembesaran tekstur kuarza 


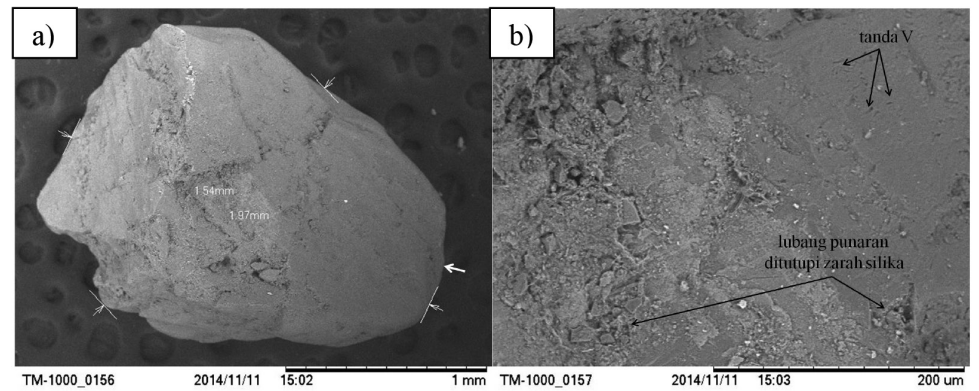

RAJAH 8. Butiran kuarza jenis E (lokaliti 29) bersaiz pasir sederhana. Anak panah menunjukkan bucu kuarza yang bulat dan menonjol. a) Imej bentuk kuarza dan b) Imej pembesaran tekstur kuarza

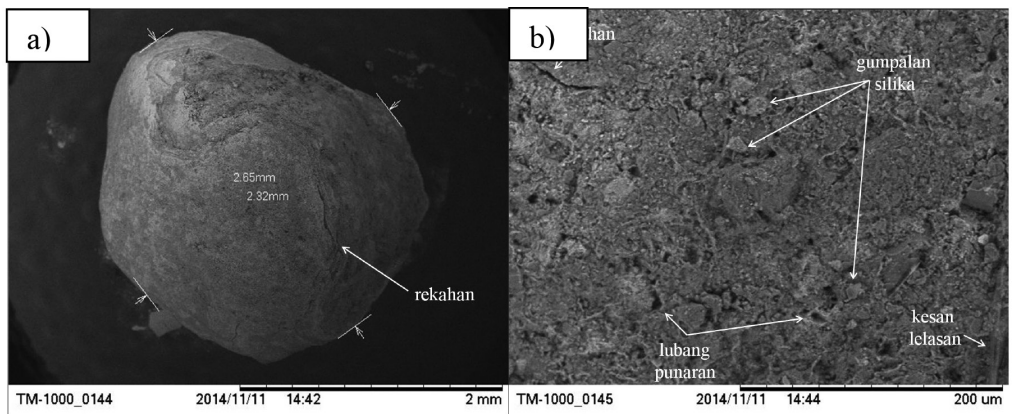

RAJAH 9. Butiran kuarza jenis E (lokaliti 29) bersaiz pasir kasar. a) Imej bentuk kuarza. Anak panah menunjukkan bucu yang menonjol. b) Imej pembesaran tekstur kuarza

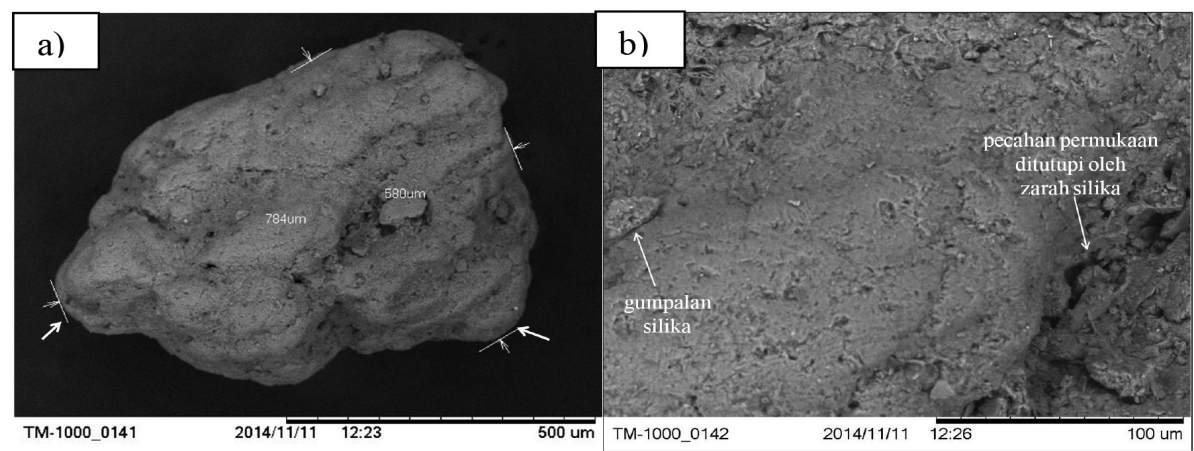

RAJAH 10. Butiran kuarza jenis E (lokaliti 31) bersaiz pasir halus a) Imej bentuk kuarza. Anak panah menunjukkan bucu yang menonjol. b) Imej pembesaran tekstur kuarza

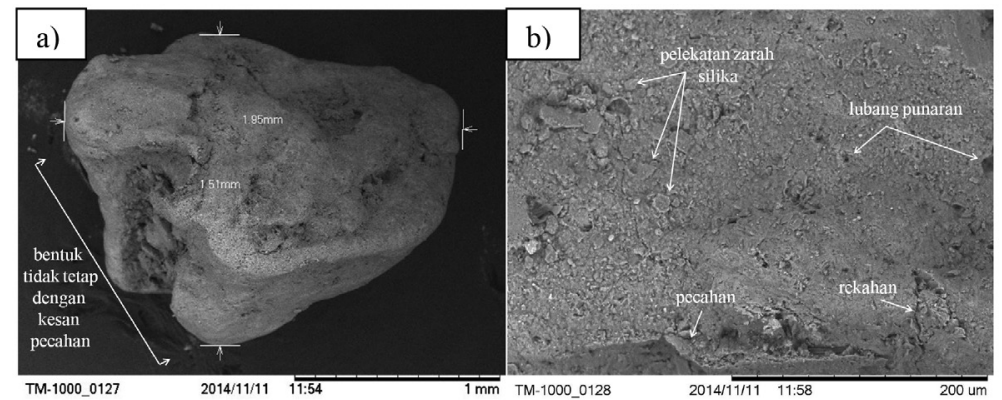

RAJAH 11. Butiran kuarza jenis E (lokaliti 31) bersaiz pasir sederhana a) Imej bentuk kuarza dan b) Imej pembesaran tekstur kuarza 


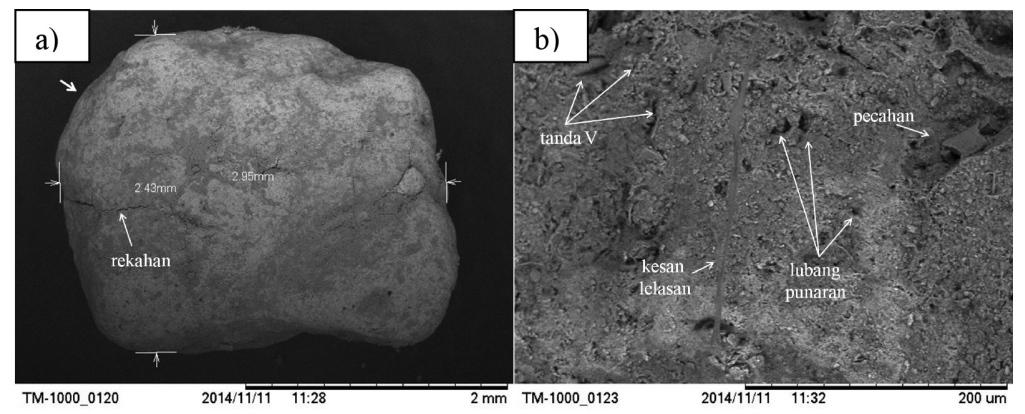

RAJAH 12. Butiran kuarza jenis E (lokaliti 31) bersaiz pasir kasar a) Imej bentuk kuarza. Anak panah menunjukkan bentuk yang hampir bulat b) Imej pembesaran tekstur kuarza

berkemungkinan adalah gumpalan silika. Butiran kuarza jenis ini berkemungkinan telah melalui tindakan mekanik yang agresif dan lama di dasar tengah laut keadaan tenaga yang tinggi dan berterusan dan kemudiannya menyebabkan bentuk asal berubah dan membentuk butiran yang hampir bulat dengan bersudut serta tekstur yang tidak teratur.

\section{KUARZA JENIS F}

Kuarza jenis F (Rajah 13, 14 dan 15) daripada lokaliti 33 menunjukkan permukaan yang sangat kasap dengan tekstur yang tidak seragam serta pecahan yang tidak seragam dan retakan yang banyak pada permukaan. Permukaannya menunjukkan pelekatan puing-puing kecil yang menyebabkan lubang punaran tertutup yang membentuk gumpalan silika. Kuarza jenis ini juga tidak menunjukkan bentuk tertentu yang malar tetapi hampir menyerupai bentuk bulat dengan terdapatnya lubang punaran dan tanda-tanda kesan $V$ yang bersaiz $>2 \mu \mathrm{m}$ pada permukaannya. Butiran kuarza jenis ini berkemungkinan telah mengalami tindakan mekanik yang sangat agresif dan lama di dasar tengah laut. Keadaan tenaga yang tinggi dan berterusan kemudiannya menyebabkan bentuk asal berubah dan membentuk butiran yang hampir bulat namun kasap serta tekstur permukaan yang tidak seragam.

\section{PerbinCANGAN}

Rajah 16 menunjukkan sempadan pemisah antara dua iaitu wilayah II dan wilayah II. Walau bagaimanapun, sempadan

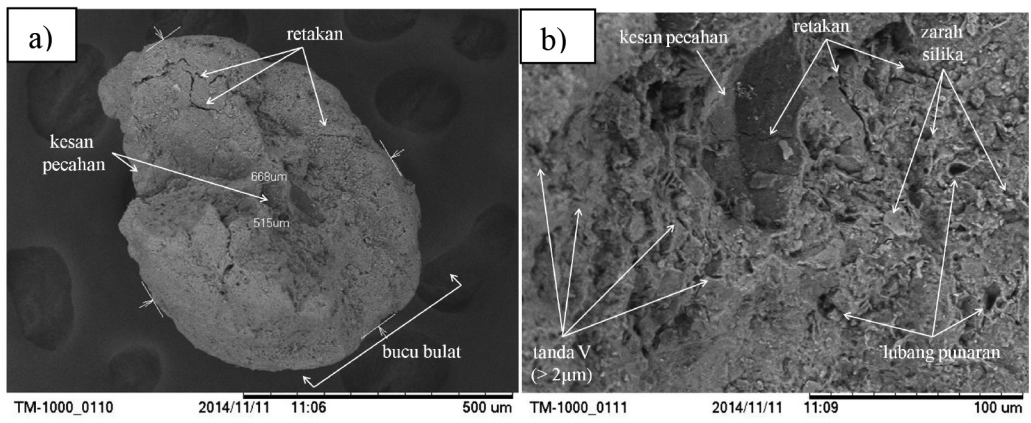

RAJAH 13. Butiran kuarza jenis F (lokaliti 33) bersaiz pasir halus a) Imej bentuk kuarza dan b) Imej pembesaran tekstur kuarza. Imej menunjukkan permukaan kuarza yang lebih kasar

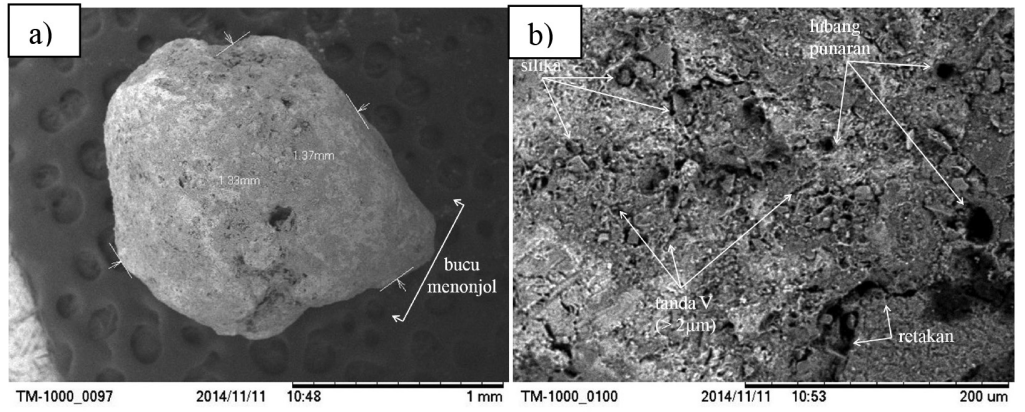

RAJAH 14. Butiran kuarza jenis F (lokaliti 33) bersaiz pasir sederhana a) Imej bentuk kuarza dan b) Imej pembesaran tekstur kuarza. Imej menunjukkan permukaan kuarza yang lebih kasar 


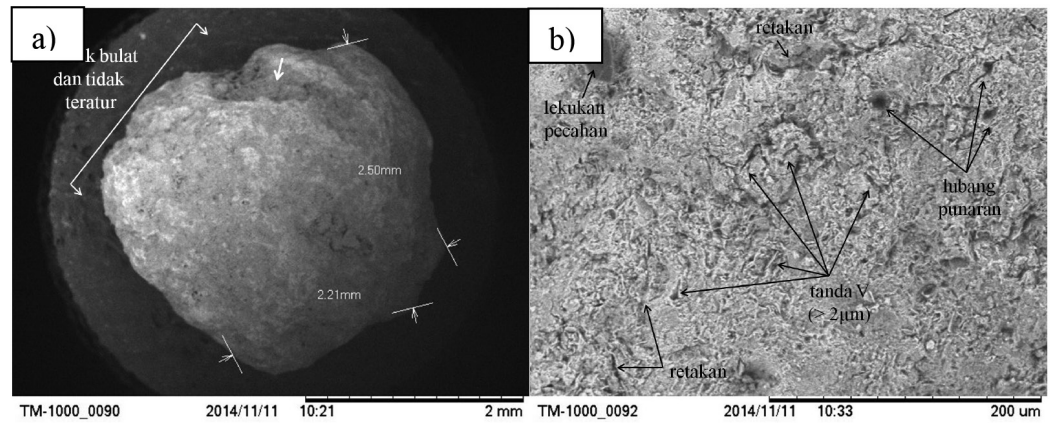

RAJAH 15. Butiran kuarza jenis F (lokaliti 33) bersaiz pasir kasar a) Imej bentuk kuarza. Anak panah menunjukkan kesan pecahan butiran kuarza. b) Imej pembesaran tekstur kuarza. Imej menunjukkan permukaan kuarza yang lebih kasar

pemisah ini berkemungkinan berubah mengikut keadaan semasa. Ringkasan ciri-ciri utama penentuan wilayah sedimentologi ditunjukkan dalam Jadual 2.

Di wilayah I, ciri-ciri sedimen yang mendominasi wilayah ini adalah dikuasai oleh butiran kuarza berbucu dan seperti serpihan yang dibawa semasa proses pengangkutan di dalam sungai. Butiran kuarza ini juga bersaiz halus dan ciri-ciri tekstur yang tidak seragam dengan pecahan pada plat dan satah permukaan yang tidak tersusun, kasap dan menggerutu pada kadar rendah sehingga sederhana.

Berdasarkan kepada ciri morfologi butir kuarza detrital yang dikaji, butiran kuarza wilayah I ditafsirkan sebagai sedimen Resen terbitan daratan. Butiran kuarza merekodkan pecahan dan lelasan yang tidak seragam pada permukaannya dengan satah yang patah menunjukkan kuarza tersebut telah mengalami beberapa kali proses angkutan dan pemendapan sebelum dienapkan ke kawasan sekitaran yang wujud sekarang. Batuan induk ini mengalami luluhawa dan melepaskan sedimen dan diangkut ke dalam saliran sama ada saliran tertib pertama, saliran tertib kedua atau saliran tertib ketiga yang kemudiannya sedimen tersebut bergabung di dalam Sungai Kelantan sebelum dilepaskan ke dalam kawasan tadahan lembangan Laut China Selatan di Kuala Besar.

Proses hakisan, angkutan dan pemendapan yang berlaku sebelum sedimen terendap di sekitaran moden sekarang menyebabkan butiran kuarza yang mempunyai ketahanan yang tinggi merekodkan sejarah dan proses yang berlaku pada bahagian permukaannya secara mikro. Menurut Darmody (1985), Douglas \& Platt (1977), Marcelino dan Stoops (1996) serta Schulz dan White (1999), morfologi permukaan kuarza merupakan satu alat pengukur sejarah yang boleh digunakan untuk menentukan proses luluhawa yang telah berlaku ke atas butiran kuarza tersebut.

Manakala, kuarza yang wujud di wilayah II pula mempunyai bentuk yang tidak tetap tetapi hampir menyerupai bentuk bulat serta sfera dengan terdapatnya lubang punaran dan tanda-tanda kesan $\mathrm{V}$ yang bersaiz $<2 \mu \mathrm{m}$ hingga $>2 \mu \mathrm{m}$ pada permukaannya. Berdasarkan

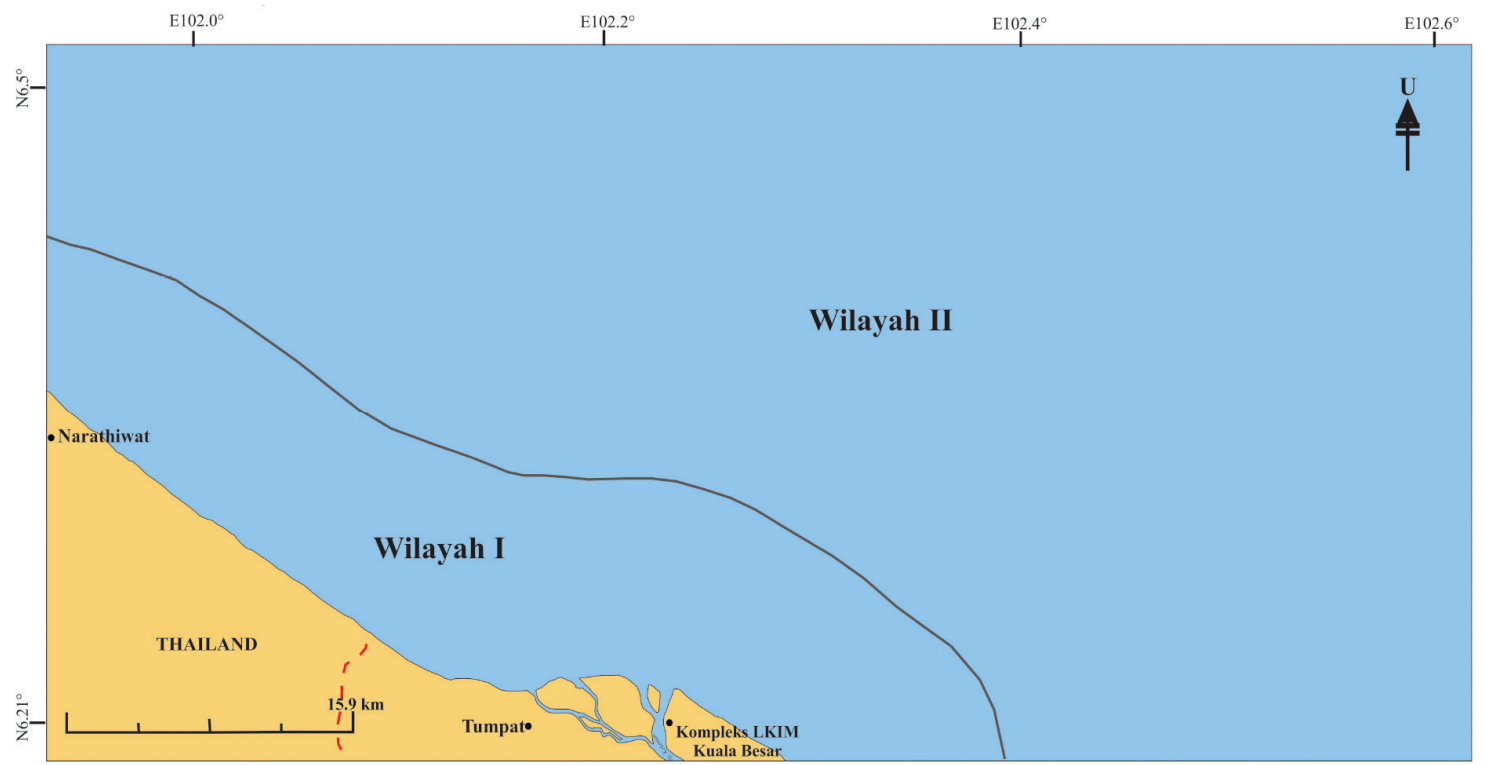

RAJAH 16. Sempadan pemisah wilayah I dan wilayah II 
JADUAL 2. Ciri utama penentuan wilayah sedimen

\begin{tabular}{|c|c|c|}
\hline Ciri utama & Wilayah I & Wilayah II \\
\hline Morfologi & Subsegi bersegi - subbulat bersegi & Subbulat bersegi - bulat subbulat-sfera \\
\hline Tekstur & $\begin{array}{l}\text { Ketidakhadiran tanda } \mathrm{V} \text { hingga } \\
\text { kehadiran tanda } \mathrm{V} \text { dengan kedalaman } \\
<2 \mu \mathrm{m} \text {, berbucu dan serpihan pecahan } \\
\text { dan lelasan yang tidak teratur }\end{array}$ & $\begin{array}{l}\text { Kehadiran tanda } V \text { dengan kedalaman } \\
\text { tanda } V<2 \mu \mathrm{m} \text { hingga } \mathrm{V}>2 \mu \mathrm{m}, \\
\text { gumpalan silika, berbucu hampir } \\
\text { bulat dan menonjol, kesan lelasan } \\
\text { yang agresif }\end{array}$ \\
\hline Sedimen baki & Tidak & Ya \\
\hline
\end{tabular}

ciri kuarza tersebut, ia menunjukkan kuarza wilayah II ini mengalami tindakan tenaga yang tinggi hingga sangat tinggi yang sinonimnya berlaku di dasar laut kerana perlanggaran atau lelasan yang sangat aktif dan agresif dengan sedimen di bahagian dasar laut (Higgs 1979; Hill \& Nadeau 1984; Hodel et al. 1988; Krinsley \& Doornkamp 1973). Kuarza yang wujud di wilayah II ini berkemungkinan mengalami proses yang agresif dan berterusan di dasar laut sejak dienapkan sekitar 5000 tahun yang lalu.

Sedimen yang wujud di wilayah ini berkemungkinan berasal daripada dua sumber genetik iaitu; sedimen Resen (sama seperti wilayah I) dan sedimen baki. Sedimen baki yang wujud di wilayah ini hasil daripada proses atau perubahan paras laut semasa usia lewat Pleistosen hingga Holosen dahulu. Menurut Bosch (1988), perubahan paras laut yang mendadak semasa usia lewat Pleistosen hingga Holosen mengubah keadaan pantai dan mengubah proses sedimentasi secara semula jadi di kawasan yang dipengaruhi oleh perubahan paras air laut. Perubahan yang berlaku ini menyebabkan paras air laut meningkat sehingga lebih $5 \mathrm{~m}$ daripada paras purata air laut normal, manakala penurunan paras air secara mendadak menyebabkan hakisan dan pemendapan semula sedimen yang wujud di kawasan pantai sekitar 5000 kalendar tahun dahulu (Tjia 1992). Berdasarkan data geokronologi daripada hasil analisis sedimentologi dan palinologi, Horton et al. (2005) menemukan perubahan paras air laut ketika usia Holosen bermula daripada paras minimum kira-kira $22 \mathrm{~m}$ sekitar 9700 hingga 9250 tahun lampau sehingga usia pertengahan Holosen iaitu sekitar 4850 hingga 4450 tahun lampau.

Berdasarkan analisis yang dijalankan, taburan sedimen dasar laut yang bermula dari kawasan laut cetek Delta Sungai Kelantan sehingga ke kawasan pelantar Laut China Selatan mempunyai ciri sedimen yang dipengaruhi oleh pelbagai faktor geologi dan geografi, berpunca daripada sedimen di daratan. Manakala sedimen yang wujud di wilayah II merupakan percampuran sedimen baki dan sedimen Resen yang wujud dalam kuantiti yang sedikit dan dikelaskan sebagai komponen lautan sub-arkos.

\section{KESIMPULAN}

Analisis mikroskopi butiran kuarza menunjukkan bahawa taburan kuarza dan sedimen di kawasan kajian boleh dibahagikan kepada dua wilayah iaitu wilayah I dan wilayah II. Wilayah I dikelaskan sebagai sedimen Resen yang berpunca daripada batuan induk di daratan sekarang dengan ciri tekstur kuarza yang pecah dan patah, serta morfologi yang dipengaruhi oleh proses hakisan, angkutan dan enapan yang berulang kali semasa di dalam sungai sebelum dienapkan di sekitaran endapan sekarang. Wilayah II pula menunjukkan sedimennya telah mengalami proses lelasan dalam jangka masa yang lama yang menghasilkan morfologi yang tidak tetap daripada subbulat bersegi sehingga hampir sfera. Tekstur permukaan kuarza menunjukkan bahawa sedimen telah mengalami lelasan dan hakisan yang agresif pada kadar tenaga yang tinggi yang secara teorinya berlaku di bahagian dasar laut. Justeru, sedimen di wilayah II ini dikelaskan sebagai genetik daripada komponen sub-arkos lautan iaitu sedimen baki yang dienapkan sekitar 5000 tahun lampau yang lalu dan diselang-selikan dengan kehadiran sedimen Resen.

\section{PENGHARGAAN}

Kajian ini dijalankan dengan bantuan geran penyelidikan FRGS/2/2014/STWN06/UKM/1/1 (Kesesuaian Tapak Warisan Geologi dan Landskap untuk Pembangunan Lestari Wilayah di Baratlaut Semenanjung Malaysia).

\section{RUJUKAN}

Basu, A. 1976. Petrology of Holocene fluvial sand derived from plutonic source rocks: implications to paleoclimatic interpretation. Journal of Sedimentary Petrology 46(3): 694-709.

Basu, A., Young, S.W., Suttner, L.J., James, W.C. \& Mack, G.H. 1975. Re-evaluation of the use of undulatory extinction and polycrystallinity in detrital quartz for provenance interpretation. Journal of Sedimentary Petrology 45(4): 873-882.

Bosch, J.H.A. 1988. The quaternary deposits in the coastal plain of Peninsular Malaysia. Report No. QG/1 of 1988, Quaternary Geological Section, Geological Survey of Malaysia.

Darmody, R.G. 1985. Wethering assessment of quartz grains: A semi quantitative approach. Soil Science Society of America Journal 49: 1322-1324.

Douglas, L.A. \& Platt, D.W. 1977. Surface morfology of quartz and age of soils. Soil Science Society of America Journal 41: 641-645.

Higgs, R. 1979. Quartz-grain surface features of MesozoicCenozoic sands from the Labrador and Western Greenland 
continental pinggirs. Journal of Sedimentary Petrology 49(2): 599-610.

Hill, P.R. \& Nadeau, O.C. 1984. Grain-surface textures of Late Wisconsinan sands from the Canadian Beaufort shelf. Journal of Sedimentary Petrology 54(4): 1349-1357.

Hodel, K.L., Reimnitz, E. \& Barnes, P.W. 1988. Microtextures of quartz grains from modern terresterial and subaqueous environments, North Slope of Alaska. Journal of Sedimentary Petrology 58(1): 24-32.

Horton, B.P., Gibbard, P.L., Milne, G.M., Morley, R.J., Purintavaragul, C. \& Stargardt, J.M. 2005. Holocene sea levels and paleoenvironments, Malay-Thai Peninsula, Southeast Asia. The Holocene 15: 1199-1213.

Kasper-Zubillaga, J.J. 2009. Roundness in quartz frains from inland and coastal dune sands, Altar Desert, Sonora, Mexico. Buletin de La Sociedad Geologica Mexicana 61(1): 1-12.

Kravitz, J.H. 1976. Textural and mineralogical characteristics of the surficial sediments of Kane Basin. Journal of Sedimentary Petrology 46(3): 710-725.

Krinsley, D.H. \& Doornkamp, J.C. 1973. Atlas of Quartz Sand Surface Textures. New York: Cambridge University Press.

Marcelino, V.\& Stoops, G. 1996. A wethering score for sandy soil materials based on the intensity of etching of quartz grains. European Journal of Soil Science 47: 7-12.

Margolis, S.V. \& Krinsley, D.H. 1974. Processes of formation and environmental occurrence of microfeaures on detrital quartz grains. America Journal of Science 274: 449-464.

Margolis, S.V. \& Krinsley, D.H. 1971. Submicroscopic frosting on aolian and subaqueous quartz sand grains. Bulletin of Geological Society of America 82: 3395-3406.

Schulz, M.S. \& White, A.F. 1999. Chemical weathering in a tropical watershed, Luquillo Mountains, Puerto Rico III: quartz dissolution rates. Geochimica et Cosmochimica Acta 63(3/4): 337-350
Suresh,G.M., Solai,A. \& Chandrasekar, N. 2010. Light minerals, XRD and SEM studies in the depositional environments between Tuticorin and Thiruchendur, South East Coast of India, Tamil Nadu. International Journal of Geomatics and Geosciences 1(2): 233-251.

Tjia, H.D. 1992. Holocene sea-level changes in the Malay-Thai Peninsula, A tectonically stable environment. Bulletin of Geological Society of Malaysia 31: 157-176.

Whalley, W.B. \& Krinsley, D.H. 1974. A scanning electron microscope study of surface textures of quartz grains from glacial environments. Sedimentology 21: 87-105.

Young, S.W. 1976. Petrographic textures of detrital polycrystalline quartz as an aid to interpreting crystalline source rocks. Journal of Sedimentary Petrology 46(3): 595-603.

Program Geologi

Pusat Pengajian Sains Sekitaran dan Sumber Alam

Fakulti Sains dan Teknologi

Universiti Kebangsaan Malaysia

43600 UKM Bangi, Selangor Darul Ehsan

Malaysia

*Pengarang untuk surat-menyurat; email: nurulafifah.mradzir@ yahoo.com

Diserahkan: 16 November 2016

Diterima: 21 Jun 2017 